\title{
ОСОБЛИВОСТІ РЕАЛІЗАЦІї ПРИНЦИПУ САМОВИЗНАЧЕННЯ НАРОДІВ
}

\author{
САДУЛА Л.М. - к.е.Н, доцент, юридичний факультет Свропейського \\ університету \\ ЛУЦИК Д.В. - студент магістратури, юридичний факультет Свропейського \\ університету \\ ШЕЛЬМУК Д.В. - студент магістратури, юридичний факультет \\ Європейського університету
}

DOI 10.32782/NP.2021.4.15

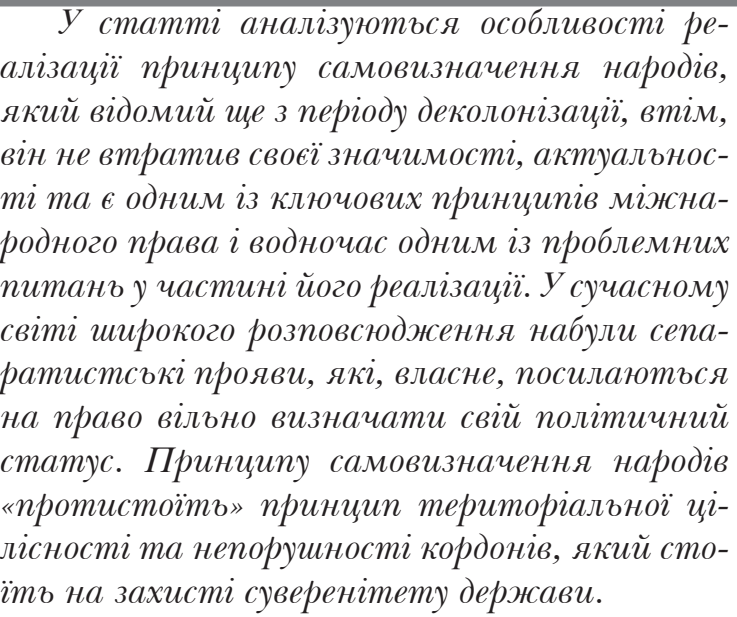

Непоодинокими є випадки, коли окремі етноси чи народи, для посилення своєї автономї, посилаючись на приниип самовизначення, виходять за межі системи дозволів, порушуючи при изому норми національного та міжнародного законодавства. А тому вкрай важливим є визначення иієї межі дозволеності, щоб відповідне право народів на самовизначення не «переростало» у бажання зруйнувати політичну, культурно-начіональну та економічну єдність держави.

Встановлено, що при реалізачй права народів на самовизначення повинні дотримуватись чіткі правові умови, які базуються на конституиійних засадах. У той же час прояви сепаратизму виходять за межі правового поля та нерідко здійснюються із застосуванням насильства. При иьому нехтуються інтереси інших націй та створюються умови для начіональної ворожнечі.
Ключові слова: приниип самовизначення народів, приничи територіальної иілісності держави, захист начіональних мениин.

Постановка проблеми

На сучасному етапі розвитку міжнародних відносин більшість політичних конфліктів у світі мають певну, хоч і формальну, юридичну основу. Порушення тих чи інших договорів або домовленостей, двозначне трактування положень таких документів є приводом до ескалації напруженості. У цьому контексті тлумачення змісту та реалізація в практичній площині принципу народів на самовизначення стає надзвичайно зручним інструментом для зацікавлених у конфлікті сторін [1, с.18].

Принцип самовизначення народів, як такий, відомий ще з періоду деколонізації (процес надання повного суверенітету окремим колоніям, підмандатним територіям). Втім, він не втратив своєї значимості та актуальності та є одним із ключових принципів міжнародного права та водночас одним із проблемних питань у частині його реалізації. У сучасному світі широкого розповсюдження набули сепаратистські прояви, які власне посилаються на право вільно визначати свій політичний статус. Водночас принципу самовизначення народів «протистоїть» принцип територіальної цілісності та непорушності кордонів, який стоїть на захисті суверенітету держави. Враховуючи сучасні реалії ідеї, щодо відокремлення можуть виходити не безпосередньо від окремого народу, а нав' язуватися ззовні. У науковій літературі з цього приводу Б.Вітошинський писав 


\section{Кримінальне право, кримінальний процес та криміналістика}

наступне: «Ідея самовизначення народів не є нова і їі в засаді загально прийнято. Але практика виявила, що те підставове право часто не є респектоване тою стороною, яка тратить на зміні сучасного стану. На факт створення ряду вільних держав, наприклад в Африці, склалися різні фактори, від пробудження національної свідомості, чи радше зродження бажання у населення жити вільним життям, до такого фактора, як політичний тиск СССР, який бачив у позбавленні західних держав їхніх колоній ослаблення» [2, с.163]. Непоодинокими є випадки, коли окремі етноси чи народи, для посилення своєї автономії, посилаючись на принцип самовизначення, виходять за межі системі дозволів, порушуючи при цьому норми національного та міжнародного законодавства. А тому вкрай важливим є визначення цієі межі дозволеності, щоб відповідне право народів на самовизначення не «переростало» у бажання зруйнувати політичну, культурно-національну та економічну єдність держави.

\section{Стан теоретичного дослідження}

Питання реалізації принципу самовизначення народів знайшли своє відображення у працях Б.В. Бабіна, М.О. Баймуратова, О.Р.Дашковської, О.В. Задорожного, О.В.Киртлюка, Т.П. Косюка, М.О. Кучинського, О.О. Мережка, П.О. Рабіновича, С.В. Соколовського, Б.Ю. Чернікова та інших. Цими вченими розглядалися питання реалізації означеного принципу, а також його співвідношення $з$ принципом територіальної цілісності та непорушності кордонів. У той же час досі не виокремлено чітких ознак, на підставі яких можна відрізняти право народу на самовизначення від суспільно небезпечного поняття сепаратизму, яке суперечить нормам національного та міжнародного законодавства.

3 огляду на зазначене метою цієї статті 6 вивчення особливостей реалізації принципу самовизначення народів.

\section{Виклад основних положень}

За твердженням В.Колісника «процес здобуття незалежності та реалізації права на самовизначення досить складний і для кожної нації (народу) є своєрідним, особливим. У кожної нації (народу) свій історичний шлях здобуття незалежності та реалізації права на самовизначення. Одні нації (народи) мали в минулому власну державу чи окремі елементи державної організації і тепер прагнуть іï відновити (як, наприклад, Тибет). Інші нації (народи) раніше не мали своєї держави, але вже усвідомили свою самобутність, неповторність, спільність інтересів і прагнуть до створення національної держави. Але всі вони мають однакове право на самовизначення» [3, с.36].

У Декларації про принципи міжнародного права, які стосуються дружних відносин і співробітництва між державами відповідно до Статуту Організації Об'єднаних Націй від 24 жовтня 1970 р. зазначено, що всі народи мають право вільно визначати свій політичний статус i здійснювати економічний, соціальний і культурний розвиток, і кожна держава повинна поважати це право. Формами здійснення народом права на самовизначення 6 створення суверенної і незалежної держави, вільне приєднання до незалежної держави або об'єднання $з$ нею, або встановлення іншого політичного статусу, вільно визначеного народом [4]. Схожі положення також передбачені і в інших міжнародних документах, таких як: Декларація Організації Об'єднаних Націй про права корінних народів від 13 вересня 2007 р., Декларація про надання незалежності колоніальним державам та народам від 14 грудня 1960 р., Міжнародний пакт про громадянські і політичні права від 23 березня 1976 р., Заключний акт Наради з безпеки та співробітництва в Европі від 1 серпня 1975 р., Міжнародний пакт про економічні, соціальні і культурні права від 3 січня 1976 р. Разом із тим, у Резолюції №1832, прийнятій 4 жовтня 2011 р. на засіданні Парламентської Асамблеї Ради Європи, вказується, що право етнічних меншин на самовизначення не передбачає автоматичного права на відділення, а в першу чергу, має бути реалізовано методом захисту прав меншин [5].

У теорії міжнародного права суть принципу самовизначення зводиться до необхідності більшості поважати права меншості у складі одного утворення. А тому самовизначення сприймають як антиколоніальний принцип, такий, що заперечує зовнішню окупацію, гарантуе всім етнічним групам та іншим народам доступ до управління державою [1, с.18- 
19]. Не випадково окремими теоретиками обстоюється позиція, що аналізований принцип не можна розглядати поза колоніальним контекстом, оскільки в інших випадках, у тому числі всіх сучасних конфліктах на цьому підгрунті, реалізація означеного права суперечитиме принципу територіальної цілісності та непорушності кордонів [6, с. 1].

У науковій літературі самовизначення як таке умовно поділяють на два різновиди: зовнішнє та внутрішнє. Так, зовнішнє полягає в тому, що кожен народ, тобто населення будьякої країни в цілому, має право не піддаватися втручанню ззовні при реалізації своїх політичних, економічних і соціальних завдань. Що стосується колоніальних народів (населення колоній), то зовнішне самовизначення означає, що колонії мають право відділитися від метрополії і стати незалежними та суверенними державами [7, с.709]. Натомість, внутрішне самовизначення полягає у праві брати участь в управлінні державою, не піддаватися дискримінації в контексті доступу до ії керівництва, а також не бути дискримінованими будь-яким чином [1, с. 19].

У той же час у науковій літературі окремими вченими ставиться під сумнів доцільність існування принципу самовизначення народів. Скажімо, С.В. Чешко наводить 3 цього приводу наступні аргументи: по-перше, відсутні чіткі та однозначні міжнародно-правові норми, які 6 розтлумачували та реалізовували таке право; по-друге, немає чітких критеріїв, які $б$ визначали суб'єкти, що мають право на етнополітичне самовизначення; по-третє, немає безперечних, з точки зору демократичних принципів, процедур здійснення цього права; по-четверте, немає способів спільних етнічних самовизначень 3 іншими правовими нормами, які 6 забезпечували підтримку політичної світової безпеки та інтереси інших етносів [8]. Очевидно, що принципом самовизначення народів нехтувати не слід, оскільки з його урахуванням відбувся розпад Російської, Австро-Угорської та Османських імперій. Окрім того, вільне облаштування свого громадського чи політичного життя є невід'ємним правом будь-якої спільноти. Втім при реалізації цього права виникають численні труднощі, які нерідко складно вирішити і дати належну правову оцінку. Так, за твердженням М.Б. Сти- ранки, самопроголошення так званих « $\mathrm{H} \mathrm{P}$ » та «ДНР», анексія Російською Федерацією АРК у засобах масової інформації трактують по-різному: від спроби реалізації права народів на самовизначення, націоналізму до сепаратизму, тероризму. Таке різноголосся щодо оцінки, на думку цього автора, пов'язане не лише із приналежністю тих чи інших осіб до відповідної сторони конфлікту, а також із відсутністю єдиного правового підходу [9, с.8].

У теорії міжнародного права, за твердженням Т.Цимбрівського, спостерігається ідея примату принципу територіальної цілісності та непорушності кордонів над принципом самовизначення народів, незважаючи на те, що всі принципи мають однакову юридичну силу. У той же час це не означає абсолютної заборони здійснення територіальних змін на підставі права на самовизначення народів. Усе частіше практики намагаються виокремити певні умови, за наявності яких народ вправі реалізувати своє право на самовизначення всупереч принципу територіальної цілісності та непорушності кордонів, а зокрема: коли мова йде про дискримінацію, геноцид, етнічні чистки, порушення внутрішнього самовизначення. У таких випадках виникає право «захисної сецеcii» $[10$, c. 76$]$.

3 цього приводу варто зазначити, що принципи самовизначення народу і територіальної цілісності та непорушності кордонів не виключають одне одного, однак фактично «взаємопроникають», а тому вкрай важливо знайти чітку межу між ними. У зв'язку з цим необхідно розглянути співвідношення поняття сепаратизму, як суспільно небезпечного явища, що полягає у протизаконному прагненні до відокремлення та права народів на самовизначення, яке регламентоване нормами законодавства.

У Статуті Організації Об'єднаних Націй від 24 жовтня 1970 р. вказується, що «територія держави не повинна бути об'єктом військової окупації, що є результатом застосування сили в порушення положень Статуту. Територія держави не повинна бути об'єктом набугтя іншою державою в результаті погрози силою або ії застосування. Жодні територіальні надбання, що є результатом погрози силою або iï застосування, неповинні визнаватися законними» (ст.1)[11]. Зазначений принцип 


\section{Кримінальне право, кримінальний процес та криміналістика}

згідно 3 нормами міжнародного публічного права, полягає в закріпленні й гарантуванні в міжнародних договорах таких правил міждержавного діалогу, які виключають можливість вчинення будь-яких дій, які прямо чи непрямо можуть порушити територіальну цілісність держави, у розумінні неподільності суші й державних кордонів, надр, повітряного простору, континентального шельфу тощо в межах державного кордону та за його межами в передбачених законом випадках [12, с.14].

Відповідно до національного законодавства України, питання законного порядку зміни території вирішуються лише всеукраїнським референдумом, який проголошується за народною ініціативою на вимогу не менш як трьох мільйонів громадян України, які мають право голосу, за умови, що підписи щодо призначення референдуму зібрано не менш як у двох третинах областей і не менш як по сто тисяч підписів у кожній області. Будь-які інші способи зміни меж території є нелегітимними (ст.72, 73, 85 Конституції України).

У рішенні Конституційного Суду України у справі за конституційним поданням виконуючого обов'язки Президента України, Голови Верховної Ради України щодо відповідності Конституції України (конституційності) Постанови Верховної Ради Автономної Республіки Крим «Про Декларацію про незалежність Автономної Республіки Крим і міста Севастополя» від 20 березня 2014 р. Справа №1-15/2014 зазначено, що згідно із загальновизнаними принципами і нормами міжнародного права народи мають право на самовизначення, яке не повинне тлумачитися як таке, що санкціонує або заохочує будь-які дії, які порушують чи підривають (повністю або частково) територіальну цілісність або політичну єдність суверенних і незалежних держав, які дотримуються принципу рівноправ'я і самовизначення народів і внаслідок цього мають уряди, які представляють інтереси всього народу на їх території без будь-яких відмінностей.

Окрім того, КСУ наголошує, «що право на самовизначення на території Автономної Республіки Крим та в місті Севастополі було реалізовано їх жителями як невід'ємною частиною всього Українського народу під час всенародного голосування на Всеукраїнському референдумі 1 грудня 1991 року. Враховуючи результати цього референдуму, Верховна Рада України від імені Українського народу - громадян України всіх національностей - 28 червня 1996 року прийняла Конституцію України, у якій, зокрема, проголосила Україну суверенною і незалежною державою та закріпила принцип її територіальної цілісності». У зв’язку 3 цим КСУ було прийнято рішення визнати такою, що не відповідає Конституції України ( 6 неконституційною), Постанову Верховної Ради Автономної Республіки Крим «Про Декларацію про незалежність Автономної Республіки Крим і міста Севастополя» від 11 березня 2014 року № 1727-6/14 [13]. 3 вищенаведеного випливає, що у рішенні КСУ мова йде про сепаратизм як незаконний спосіб відокремлення АРК від території України, а не жодним чином про право народу на самовизначення. При реалізації цього права повинні дотримуватись чіткі правові умови, які базуються на конституційних засадах. 3 цього приводу С.В. Сьомін справедливо зауважує, що самовизначення повинно відбуватися без будь-якої дискримінації населення іншого етносу лише за умов абсолютного рівноправ'я всіх громадян, пріоритету прав людини без переваг для корінних етносів [14, с.148]. У той же час прояви сепаратизму виходять за межі правового поля та нерідко здійснюються із застосуванням насильства. При цьому нехтуються інтереси інших націй та створюються умови для національної ворожнечі.

\section{Висновки}

Таким чином, колізія між принципом народу на самовизначення та принципом територіальної цілісності та непорушності кордонів нерідко створює практичні труднощі у визначенні межі між ними, а тому призводить до неоднозначної реакції світового співтовариства на протиправні зазіхання на територіальну цілісність держави.

\section{入iтература}

1. Косюк Т. П. Актуальні аспекти тлумачення та реалізації принципу самовизначення народів. Наукові записки НаУКМА. Політичні науки. 2014. Т. 160. С. 17-22.

2. Вітошинський Б. Збірник праць. Війна i міжнародне право - Українська видавнича спілка ім. Ю. Аипи, К., 2014. 559 с. 
3. Колісник В. Національний суверенітет та право нації на самовизначення. Вісник Академї правових наук Украӥни. - Х. : Право, 2001. №1(24). С. 33-39

4. Декларация о принципах международного права, касающихся дружественных отношений и сотрудничества между государствами всоответствии с Уставом Организации ОбъединенныхНаций від 24.10.1970 р. [Електронний ресурс]. - Режим доступу: http://zakon4. rada.gov.ua/laws /show/995 569.

5. Национальный суверенитет и государственность в современном международном праве Резолюция 1832 (2011) [Электронный pecypc]. - Режим доступа: http://www.coe.int/t/ parliamentary_assembly/Brussian__documents2 rus.asp

6. Borgen Christopher. The Language of Lawand the Practice of Politics: Great Powersand the Rhetoric of Self-Determination in the Cases of Kosovo and South Ossetia (September 11, 2009) [Electronic resource] / Chicago Journal of International Law. - 2009. - Vol. 10. - 33 p. (St. John's Legal Studies Research Paper No. 09-0176). Mode of access: http://papers. ssrn.com/sol3/papers.cfm?abstract_id=1472068\#\#. - Title from the screen.

7. Черніков Б.Ю. Право народу на самовизначення як принцип міжнародного права. Молодий вчений. №10 (50). 2017 р. С.708-711

8. Чешко С.В. Кризис доктрины самооприделения. История РФ. Главный исторический портал страны. URL: https://histrf.ru/read/ articles/krizis-doktriny-samoopriedielieniia

9. Стиранка М.Б. Кримінально-правова характеристика сепаратизму в Україні: дис. канд. юрид. наук. Спец.: 12.00.08 - кримінальне право та кримінологія; кримінально-виконавче право. Аьвівський державний університет внутрішніх справ. Аьвів. 2021 р. 247 с.

10. Цимбрівський Т. Принцип рівноправ’я та самовизначення народів у сучасному міжнародному праві. Вісник Запорізъкого наиіонального університету. 2012. № 2(1). С. 74-78.

11. Декларація про принципи міжнародного права, що стосуються дружніх відносин та співробітництва між державами відповідно до Статуту Організації Об’єднаних Націй від 24.10.1970 / [Електронний ресурс] - Режим доступу: http://zakon3.rada.gov. ua/laws/ show/995 569

12. Жалій Т.В. Міжнародні принципи територіальної цілісності та непорушності кордонів держави в контексті необхідності їхнього вивчення в правознавчих курсах ВН3

\section{SUMMARY}

The article analyzes the peculiarities of the implementation of the principle of self-determination of peoples, which is known since the period of decolonization, but it has not lost its significance, relevance and is one of the key principles of international law and at the same time one of the problematic issues. In the modern world, separatist manifestations have become widespread, which in fact refer to the right to freely determine one's political status. The principle of territorial self-determination of peoples is "opposed" by the principle of territorial integrity and inviolability of borders, which stands for the protection of state sovereignty.

There are many cases when individual ethnic groups or peoples, in order to strengthen their autonomy, referring to the principle of selfdetermination, go beyond the system of permits, while violating the norms of national and international law. Therefore, it is extremely important to determine this limit of permissibility, so that the corresponding right of peoples to self-determination does not "grow" into a desire to destroy the political, cultural, national and economic unity of the state.

It is established that in exercising the right of peoples to self-determination, clear legal conditions must be observed, which are based on constitutional principles. At the same time, manifestations of separatism go beyond the legal field and are often carried out with the use of violence. At the same time, the interests of other nations are neglected and conditions for national enmity are created.

Key words: principle of national selfdetermination, principle of territorial integrity, protection of national minorities.

України. Альманах міжнародного права. Випуск 10. 2018 p. C.12-19

13. Рішення Конституційного Суду України у справі за конституційним поданням виконуючого обов'язки Президента України, Голови Верховної Ради України щодо відповідності Конституції України (конституційності) Постанови Верховної Ради Автономної Республіки Крим «Про Декларацію про незалежність Автономної Республіки Крим і міста Севастополя» від 20 березня 2014 р. Справа №1-15/2014. URL: https://zakon.rada.gov.ua/ laws/show/v003p710-14\#Text

14. Сьомін C.B. Сепаратизм як загроза національній безпеці України. Стратегічні пріоритети. №3 (32). 2014. С. 143-149 